\title{
ERRATA
}

\section{Changes in Cell Size and Shape Associated with Changes in the Replication Time of the Chromosome of Escherichia coli}

\author{
A. ZARITSKY AND R. H. PRITCHARD \\ Department of Genetics, The University, Leicester LE1 7RH, England
}

Volume 114, no. 2, p. 826, column 2, equation 3: Should read

$$
\overline{\mathrm{G}} / \overline{\mathrm{M}}=\frac{\tau}{k \mathrm{C} \ln 2}\left(1-2^{-\mathrm{c} / \tau}\right)
$$

p. 835, paragraph 3, 2nd sentence: Should read "If the rate of extension per site were constant, the average cell length would be a function of $2^{\mathrm{D} / \tau} \cdot \tau$, and cell length would decrease as growth rate increased."

\section{Use of External, Biosynthetic, and Organelle Arginine by Neurospora}

K. N. SUBRAMANIAN, RICHARD L. WEISS, AND ROWLAND H. DAVIS

Department of Botany, University of Michigan, Ann Arbor, Michigan 48104

Volume 115, no. 1, p. 284, 2nd column, line 3: Change sentence beginning with "The organelle ..." to read "The organelle is distinct from mitochondria, but in the absence of identification by criteria other than sedimentation, it will be called a vesicle, and its contents, the vesicular pool." 